\title{
Formulasi dan Evaluasi Fisik Masker Wajah Gel Peel Off Ekstrak Kulit Buah Naga Merah (Hylocereus Polyrhizus)
}

\author{
Yenni Puspita Tanjung*, Anti Malep Rokaeti \\ Program Studi Diploma III Farmasi Akademi Farmasi Bumi Siliwangi Bandung \\ *Email korespondensi: yennipuspitatanjung85@gmail.com \\ (Submit 15/03/2019, Revisi 05/09/2019, Diterima 20/12/2019)
}

\begin{abstract}
Abstrak
Buah naga merah (Hylocereus polyrhizus) merupakan salah satu buah yang memiliki banyak manfaat bagi kesehatan, dimana kandungan antioksidan tertinggi berada pada kulit buah naga merah. Penelitian ini bertujuan untuk mengetahui formulasi masker wajah gel peel off ekstrak kulit buah naga merah (Hylocereus polyrhizus) dengan variasi konsentrasi polivinil alkohol (PVA) yang memenuhi syarat evaluasi fisik gel. Masker wajah gel peel off dengan kandungan ekstrak kulit buah naga merah dibuat dalam tiga formula dengan variasi konsentrasi polivinil alkohol (F1 : 6\%, F2 : 10\%, dan F3 : 14\%) sebagai pembentuk lapisan film. Evaluasi fisik yang dilakukan, yaitu berupa uji organoleptis, uji $\mathrm{pH}$, uji viskositas, uji waktu kering, dan uji daya sebar yang dilakukan selama penyimpanan 28 hari pada suhu ruang $\left(25^{\circ} \mathrm{C}\right)$ dan suhu dingin $\left(8^{\circ} \mathrm{C}\right)$. Hasil penelitian menunjukkan bahwa formula masker wajah gel peel off ekstrak kulit buah naga merah memenuhi syarat evaluasi fisik selama penyimpanan 28 hari pada suhu dingin untuk formula F2 dan F3. Hasil evaluasi fisiknya yaitu kedua formula memiliki bentuk yang konsisten, tidak mengalami perubahan warna dan bau, memiliki $\mathrm{pH}$ yang memenuhi syarat dan stabil yaitu berada pada $\mathrm{pH} 6$, pada uji daya sebar dan uji waktu kering memenuhi syarat yaitu daya sebar antara 5,12-6,82 cm dan waktu kering antara 25-30 menit. Formula masker wajah gel peel off ekstrak kulit buah naga merah dengan variasi konsentrasi PVA yang memenuhi syarat evaluasi fisik gel selama penyimpanan 28 hari pada suhu dingin adalah F2 dan F3.
\end{abstract}

Kata kunci: antioksidan, masker wajah gel peel off, kulit buah naga merah, Hylocereus polyrhizus

\section{Outline}

- Pendahuluan

- Metode

- Hasil dan Pembahasan

- Kesimpulan

- Daftar Pustaka

\section{Pendahuluan}

Kulit merupakan pelindung tubuh paling luar dan kontak langsung dengan polusi lingkungan yang penuh dengan radikal bebas, oleh karena itu penting untuk melindungi kulit ${ }^{1}$. Kulit secara alami dapat mengalami penuaan dini dan hal ini dapat disebabkan 
oleh sumber radikal bebas yang berasal dari lingkungan seperti polusi udara, sinar matahari, gesekan mekanik, suhu panas atau dingin dan reaksi oksidasi yang berlebihan yang dapat menyebabkan reaksi oksidatif seperti kerusakan sel atau kematian sel. Penuaan kulit dapat menurunkan elastisitas kulit dan menyebabkan kerusakan melanin².

Antioksidan merupakan senyawa yang dapat menetralkan radikal bebas reaktif menjadi bentuk tidak reaktif yang relatif stabil sehingga dapat melindungi sel dari efek bahaya radikal bebas ${ }^{3}$. Antioksidan berperan sangat penting dalam melindungi kulit karena antioksidan menyerap radikal bebas dan kembali dinetralisir. Berdasarkan sumber perolehannya ada dua macam antioksidan, yaitu antioksidan alami dan antioksidan sintetik. Adanya kekhawatiran akan kemungkinan efek samping yang belum diketahui dari antioksidan sintetik menyebabkan antioksidan alami menjadi alternative yang sangat dibutuhkan ${ }^{4,2}$.

Salah satu sumber antioksidan alami adalah buah naga merah (Hylocereus polyrhizus) terutama pada kulitnya. Kulit buah naga mengandung vitamin $\mathrm{C}$, vitamin $\mathrm{E}$, vitamin $\mathrm{A}$, alkaloid, terpenoid, flavonoid, tiamin, niasin, piridoksin, kobalamin, fenolik, karoten, dan fitoalbumin ${ }^{5}$.

Penelitian yang dilakukan oleh Nurliyana, et al (2010) bahwa kulit buah naga merah (Hylocereus polyrhizus) memiliki aktivitas antioksidan lebih tinggi dibandingkan daging buahnya $^{6}$. Selain itu, pada penelitiannya tersebut disebutkan bahwa dalam $1 \mathrm{mg} / \mathrm{ml}$ kulit buah naga merah mampu menghambat $83,48 \pm 1,02 \%$ radikal bebas, sedangkan pada daging buah naga hanya mampu menghambat radikal bebas sebesar 27,45 $\pm 5,03 \%$.

Kulit wajah dapat dilindungi dengan menggunakan berbagai kosmetik yang penggunaannya ditujukan untuk wajah. Sediaan kosmetik baik krim, lotion, masker atau masker wajah peel off dapat digunakan memperbaiki masalah kulit pada wajah seperti keriput, penuaan, jerawat dan juga dapat digunakan untuk menutup pori-pori. Masker wajah peel off dapat digunakan untuk membersihkan dan melembabkan kulit. Sebagian besar masker wajah peel off dibuat dari polimer yang dapat membentuk lapisan tipis pada wajah ${ }^{1}$. Penggunaan sediaan masker wajah peel off sangat mudah dalam pemakaian karena tidak menimbulkan rasa sakit, gel cepat kering, setelah gel mengering dapat dibersihkan dengan cara mengangkat lapisan gel dari kulit tanpa menggunakan air, sehingga lebih praktis dalam penggunaannya ${ }^{2}$.

PVA digunakan untuk memberikan efek peel-off karena memiliki sifat adhesive atau bisa membentuk lapisan film yang mudah dikelupas setelah PVA mengering (Priani dkk., 2015). PVA merupakan salah satu pembentuk lapisan film yang banyak digunakan dalam sediaan topikal karena bersifat biocompatible?

Berdasarkan uraian diatas, maka penulis ingin melakukan penelitian "Formulasi dan Evaluasi Fisik Masker Wajah Gel Peel off Ekstrak Kulit Buah Naga Merah (Hylocereus polyrhizus)"

\section{Metode}

\section{A. Bahan}

Bahan yang digunakan dalam penelitian ini adalah ekstrak kulit buah naga merah yang 
dibeli dari Lansida Herbal, polivinil alkohol (PT. Brataco Chemica), HPMC (PT. Brataco Chemica), gliserin (PT. Brataco Chemica), metilparaben dan propilparaben (Global Chemind Megatrading), aquadestilata (Central Bandung Raya).

\section{B. Metode}

1. Formulasi Masker Gel Peel Off

Tabel 1. Formulasi Masker Gel Peel Off Ekstrak Kulit Buah Naga Merah

\begin{tabular}{|l|c|c|c|}
\multicolumn{1}{|c|}{ Bahan } & \multicolumn{3}{|c|}{ Jumlah (\%) } \\
\hline \begin{tabular}{l|c|c|} 
Ekstrak kulit buah \\
naga merah
\end{tabular} & 0,1 & 0,1 & 0,1 \\
\hline PVA & 6 & 10 & 14 \\
\hline HPMC & 1 & 1 & 1 \\
\hline Gliserin & 10 & 10 & 10 \\
\hline Methylparaben & 0,2 & 0,2 & 0,2 \\
\hline Propylparaben & 0,05 & 0,05 & 0,05 \\
\hline Aquadest & ad 100 & ad 100 & ad 100 \\
\hline
\end{tabular}

Pembuatan Masker Wajah Gel Peel Off diawali dengan ditimbangnya setiap bahan. Polivinil alkohol (PVA) digerus dahulu hingga lebih halus lalu dikembangkan dengan air panas $\left(80^{\circ} \mathrm{C}\right)$, kemudian diaduk diatas waterbath dengan suhu konstan $80^{\circ} \mathrm{C}$ hingga terlarut sempurna. Larutkan gliserin dengan air panas, kemudian masukkan ke dalam massa PVA, lalu aduk hingga homogen (campuran A). Metilparaben dan propilparaben digerus dahulu, larutkan masing-masing dengan air mendidih dan diaduk di atas tangas api hingga terlarut, lalu masukkan ke dalam campuran $A$, aduk hingga homogen (campuran B). HPMC digerus terlebih dahulu, lalu kembangkan HPMC tersebut dengan aquadest dingin, lalu setelah mengembang masukkan ke dalam campuran $B$, aduk hingga homogen (campuran C). Larutkan ekstrak kental kulit buah naga merah dengan aquadest secukupnya, lalu masukkan ke dalam campuran $\mathrm{C}$, aduk hingga homogen. Tambahkan aquadest hingga $100 \mathrm{ml}$, aduk hingga homogen. Kemas dengan wadah tertutup rapat. Diamkan sediaan masker wajah gel peel off selama 24 jam untuk menghilangkan gelembung udara yang terbentuk pada sediaan masker gel sebelum dilakukan pengujian.

Pada penelitian ini juga dibuat blanko yang digunakan sebagai pembanding. Proses pembuatan blanko masker wajah gel peel off sama dengan proses pembuatan masker wajah gel peel off yang mengandung ekstrak kulit buah naga merah namun pada blanko masker wajah gel peel off tidak ditambahkan ekstrak kulit buah naga merah.

\section{Evaluasi Fisik}

1. Uji Organoleptik

Uji organoleptik yang dilakukan meliputi perubahan bentuk (konsistensi), warna dan bau dari sediaan masker wajah gel peel off yang dilakukan secara visual selama penyimpanan 28 hari pada suhu ruang dan suhu dingin 8 .

\section{Uji pH}

Pengujian $\mathrm{pH}$ pada sediaan masker gel peel off menggunakan stik $\mathrm{pH}$ universal. Pengujian dilakukan selama 28 hari, yaitu pada hari ke-1, 7, 14, 21, dan 28. 


\section{Uji Viskositas}

Pengujian dilakukan selama 28 hari, yaitu pada hari ke-1, 7, 14, 21, dan 28. Pengujian viskositas pada sediaan masker wajah gel peel off menggunakan viskometer Brookfield LV. Pengukuran viskositas dilakukan dengan menggunakan sampel sebesar $\pm 150 \mathrm{ml}$ yang disimpan pada wadah, kemudian diatur spindle yang sesuai, lalu spindle dicelupkan ke dalam sampel sampai batas yang terdapat pada spindle, kecepatan diatur dan nilai viskositas akan terbaca. Nilai viskositas yang terbaca (dial reading) kemudian dikalikan dengan nilai faktor yang telah ditentukan berdasarkan pada jenis spindel dan kecepatan yang digunakan sehingga didapat viskositas sampel ${ }^{8}$.

\section{Uji Waktu Kering}

Pengujian waktu sediaan mengering dilakukan dengan mengamati waktu yang diperlukan sediaan untuk mengering, yaitu waktu dari saat mulai dioleskannya masker wajah gel pada kaca hingga benar-benar terbentuk lapisan yang kering ${ }^{10}$.

\section{Uji Daya Sebar}

Uji daya sebar pada masker wajah gel peel off dilakukan dengan menimbang masker gel sebanyak 0,5 gram kemudian diletakkan ditengah kaca bulat berskala. Di atas gel diletakkan kaca bulat lain atau bahan transparan lain dan pemberat sehingga berat kaca bulat dan pemberat 150 gram, didiamkan 1 menit, kemudian dicatat diameter penyebarannya ${ }^{11,12}$.

\section{Hasil dan Pembahasan}

\section{A. Formulasi Masker Wajah Gel Peel Off}

Kualitas fisik masker wajah gel peel off dipengaruhi oleh komposisi bahan-bahan yang digunakan. Menurut Priani dkk (2015), webagai pembentuk lapisan film digunakan polivinil alkohol (PVA). PVA digunakan untuk memberikan efek peel-off karena memiliki sifat adhesif atau bisa membentuk lapisan film yang mudah dikelupas setelah PVA mengering. PVA merupakan salah satu pembentuk lapisan film yang banyak digunakan dalam sediaan topikal karena bersifat biocompatible ${ }^{7}$. Sebagai humektan atau pelembab digunakan gliserin. Penambahan bahan higroskopis seperti gliserin akan mampu mencegah kehilangan air. Gliserin berfungsi sebagai humektan yang memiliki kemampuan mengurangi hidrasi kulit sehingga tetap dalam kondisi lembab dan tidak kering ${ }^{13}$. Sebagai peningkat viskositas digunakan HPMC. HPMC akan membentuk gel yang bening, jernih, bersifat netral dan mempunyai viskositas yang stabil dalam penyimpanan jangka panjang ${ }^{14}$.

Sediaan masker gel peel off dengan pelarut air rentan terhadap pertumbuhan bakteri oleh karena itu digunakan pengawet. Pengawet yang digunakan berupa kombinasi metil paraben dan propil paraben karena aktivitas metil paraben dapat diperbaiki dengan menggunakan kombinasi paraben yang memiliki efek sinergis ${ }^{14}$.

Proses pembuatan sediaan masker wajah gel peel off dimulai dengan mengembangkan PVA dalam air panas $80^{\circ} \mathrm{C}$ karena PVA terdispersi dalam $80 \%$ air panas $\left(80^{\circ} \mathrm{C}\right)^{15}$.

Sebelum dilakukan pengujian, sediaan didiamkan selama 48 jam agar gelembung udara yang terperangkap dalam sediaan lepas ${ }^{15}$, namun pada penelitian ini, sediaan didiamkan selama 24 jam karena dengan waktu 24 jam gelembung udara yang 
terperangkap dalam sediaan sudah tidak ada. Sediaan harus terhindar dari gelembung udara, karena dengan adanya udara yang terperangkap akan menyebabkan perubahan $\mathrm{pH}$ sediaan. Penurunan $\mathrm{pH}$ dapat terjadi karena pengaruh $\mathrm{O} 2$ yang bereaksi dengan air dalam sediaan masker gel peel off sehingga menjadi asam ${ }^{8}$.

\section{B. Evaluasi Fisik}

1. Uji Organoleptik

Pada penyimpanan suhu ruang blanko tidak mengalami perubahan sedangkan sediaan masker wajah gel peel off ekstrak kulit buah naga merah mengalami perubahan warna di hari ke-7, yaitu sediaan masker gel menjadi warna kuning transparan yang sebelumnya berwarna merah muda transparan. Hal ini dapat terjadi karena adanya komponen pada ekstrak kulit buah naga merah yang teroksidasi seperti asam askorbat (vitamin C) yang terkandung dalam kulit buah naga merah, dimana metabolit sekunder berupa asam askorbat (vitamin $\mathrm{C}$ ) memiliki struktur kimia terdiri dari 6 rantai atom $\mathrm{C}$ dan kedudukannya tidak stabil $\left(\mathrm{C}_{6} \mathrm{H}_{8} \mathrm{O}_{6}\right)$, sehingga mudah bereaksi dengan $\mathrm{CO}_{2}$ di udara menjadi asam dehidroaskorbat ${ }^{16}$, selain itu flavonoid tidak stabil terhadap perubahan pengaruh oksidasi, cahaya dan perubahan kimia. Hal ini terjadi dikarenakan wadah yang digunakan untuk masker wajah gel peel off kurang tertutup rapat sehingga udara dari lingkungan dapat masuk.

Pengamatan secara organoleptik menunjukkan bahwa sediaan masker gel peel off ekstrak kulit buah naga merah tidak mengalami perubahan warna selama penyimpanan pada suhu dingin, hal ini dikarenakan beberapa kandungan senyawa dalam ekstrak kulit buah naga merah seperti vitamin $\mathrm{C}$ dan flavonoid pada penyimpanan suhu dingin lebih stabil dibandingkan dengan penyimpanan pada suhu ruang.

\section{Uji pH}

Blanko masker gel peel off pada suhu ruang di hari ke-1 memiliki pH 7, dimana $\mathrm{pH} 7$ tidak termasuk ke dalam persyaratan $\mathrm{pH}$ kulit, yaitu 4,5-6,59.

Tabel 2. Hasil pengujian $\mathrm{pH}$ pada sediaan masker gel peel off

\begin{tabular}{|c|c|c|c|c|c|}
\hline \multirow{3}{*}{ Formula } & \multicolumn{5}{|c|}{$\mathrm{pH}$} \\
\hline & \multicolumn{4}{|c|}{ Hari ke-Hari ke- Hari ke-Hari ke- } & \multirow{2}{*}{$\begin{array}{c}\text { Hari } \\
\text { ke-28 }\end{array}$} \\
\hline & 1 & 7 & 14 & 21 & \\
\hline \multicolumn{6}{|c|}{ Suhu ruang } \\
\hline$F 1 \mathrm{E}$ & 6 & 6 & 6 & 5 & 5 \\
\hline F2E & 6 & 6 & 6 & 5 & 5 \\
\hline F3E & 6 & 6 & 6 & 5 & 5 \\
\hline F1 B & 7 & 6 & 6 & 6 & 6 \\
\hline F2 B & 7 & 6 & 6 & 6 & 6 \\
\hline F3 B & 7 & 6 & 6 & 6 & 6 \\
\hline \multicolumn{6}{|c|}{ Suhu dingin } \\
\hline F1 E & 6 & 6 & 6 & 6 & 6 \\
\hline F2E & 6 & 6 & 6 & 6 & 6 \\
\hline F3E & 6 & 6 & 6 & 6 & 6 \\
\hline F1 B & 6 & 6 & 6 & 6 & 6 \\
\hline F2 B & 6 & 6 & 6 & 6 & 6 \\
\hline F3 B & 6 & 6 & 6 & 6 & 6 \\
\hline
\end{tabular}

Keterangan: F1 E (PVA 6\%); F2 E (PVA 10\%); F3 E (PVA 14\%) : sediaan masker gel yang mengandung ekstrak kulit buah naga merah, F1 B (PVA 6\%); F2 B (PVA 10\%) ; F3 B (PVA $14 \%)$ : blanko 
Hal ini dapat terjadi karena sediaan masker wajah gel peel off menggunakan pelarut air sehingga masker wajah gel peel off memiliki kandungan air yang banyak dimana air memiliki $\mathrm{pH}$ netral $(\mathrm{pH} 7)$, namun pada hari ke-7 $\mathrm{pH}$ sediaan menurun menjadi 6 dan $\mathrm{pH}$ tetap pada nilai 6 sampai hari ke-28. Sedangkan pada sediaan masker gel peel off ekstrak kulit buah naga merah di hari ke-1 memiliki pH 6 namun pada hari ke-21 dan 28 $\mathrm{pH}$ mengalami penurunan menjadi ${ }^{5}$. Penurunan $\mathrm{pH}$ dapat terjadi karena pengaruh $\mathrm{O}_{2}$ yang bereaksi dengan air dalam sediaan masker gel peel off sehingga menjadi asam8. Meskipun terjadi penurunan pada masker wajah gel peel off ekstrak kulit buah naga merah namun $\mathrm{pH}$ sediaan masih memenuhi syarat $\mathrm{pH}$ kulit, yaitu $\mathrm{pH} 4,5$ sampai $6,5{ }^{9}$.

$\mathrm{pH}$ sediaan masker gel peel off baik blanko maupun sediaan yang mengandung ekstrak kulit buah naga merah selama masa penyimpanan 28 hari pada suhu dingin dapat dikatakan konstan dari hari ke-1 hingga hari ke-28 berada pada $\mathrm{pH} 6$.

3. Uji Viskositas

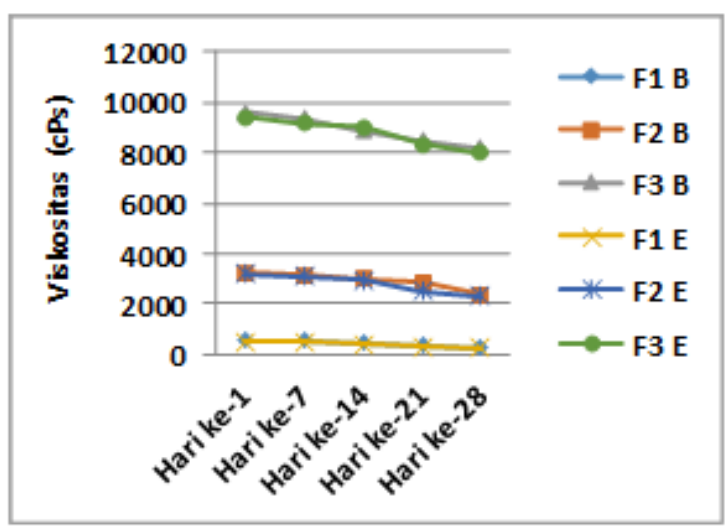

Gambar 1. Grafik Viskositas Masker Wajah Gel Peel Off Penyimpanan pada Suhu Ruang

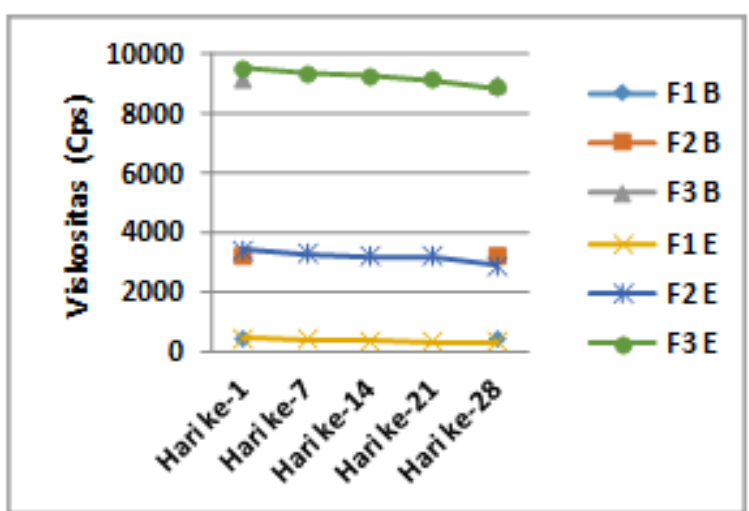

Gambar 2. Grafik Viskosıtas Ivlasker vvajan vel reeı UIr renyimpanan pada Suhu Dingin

Hasil pengujian viskositas pada ketiga formula dengan variasi konsentrasi PVA 6\%, $10 \%$ dan $14 \%$ menunjukkan ketiga formula memiliki viskositas yang berbeda-beda, yaitu F1 memiliki viskositas paling rendah, hal ini disebabkan karena semakin meningkat konsentrasi PVA dapat meningkatkan viskositas sediaan masker wajah gel peel off ${ }^{17}$. Peningkatan konsentrasi PVA dan HPMC dapat meningkatkan jumlah serat polimer sehingga semakin banyak juga cairan yang tertahan dan diikat oleh agen pembentuk gel sehingga viskositas sediaan menjadi meningkat ${ }^{18}$. 
Masker wajah gel peel off selama penyimpanan 28 hari pada suhu ruang dan suhu dingin mengalami penurunan viskositas, jika dilihat dari nilai viskositas pada hari ke-1 dan hari ke-28 pada penyimpanan sediaan di suhu dingin bahwa penurunan viskositas pada suhu ruang lebih besar dibanding dengan penyimpanan sediaan pada suhu dingin, hal ini dapat terjadi karena suhu dan waktu penyimpanan berpengaruh terhadap viskositas, dimana semakin tinggi suhu maka viskositas semakin kecil dan semakin lama penyimpanan maka semakin menurun pula viskositas sediaan, penurunan tersebut terjadi karena semakin lama waktu penyimpanan maka semakin lama pula sediaan terpengaruh oleh lingkungan, misalnya udara. Kemasan yang kurang kedap dapat menyebabkan sediaan menyerap uap dari dari luar sehingga menambah volume air dalam sediaan ${ }^{8}$.

4. Uji Waktu Kering

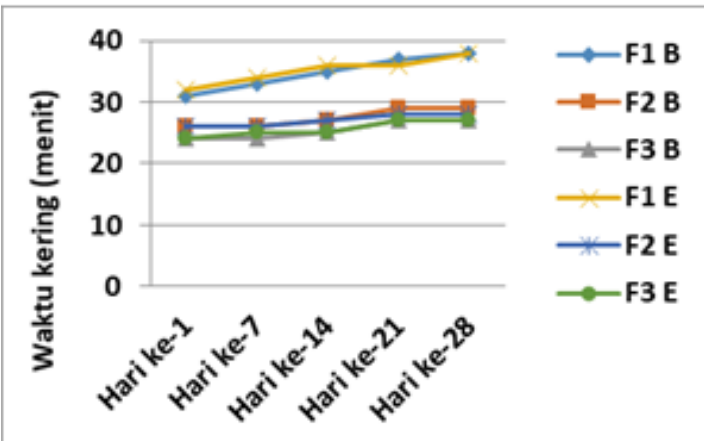

Gambar 3. Grafik Waktu Kering Masker Wajah Gel Peel Off Penyimpanan pada Suhu Ruang

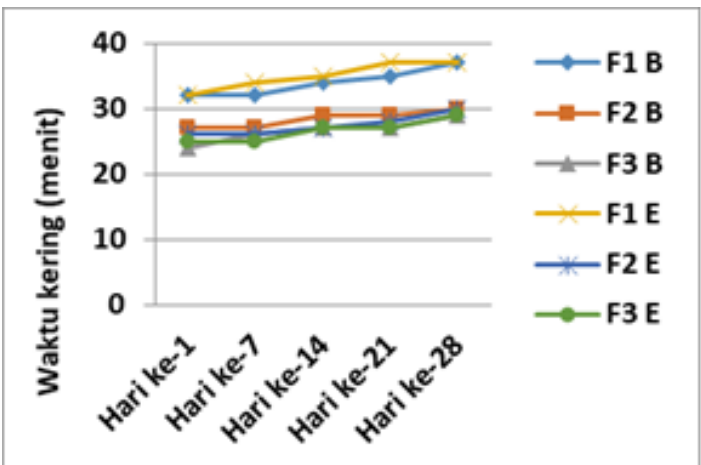

Gambar 4. Grafik Waktu Kering Masker Wajah Gel Peel Off Penyimpanan pada Suhu Dingin

Hasil uji waktu kering menunjukkan bahwa waktu kering dari F1 tinggi sehingga tidak memenuhi syarat waktu kering, yaitu 15-30 menit ${ }^{9}$, sedangkan pada F2 dan F3 memenuhi syarat waktu kering sediaan masker wajah gel peel off. Perbedaan waktu kering tersebut karena dipengaruhi oleh jumlah PVA, dimana semakin besar konsentrasi PVA maka kemampuan waktu mengering semakin cepat, hal ini dapat disebabkan oleh banyaknya kandungan air pada setiap formula yang dapat memperlambat penguapan dan pembentukkan lapisan film pada masker gel ${ }^{17}$.

Waktu kering ketiga formula pada penyimpanan selama 28 hari di suhu ruang dan suhu dingin mengalami kenaikan, waktu kering F1 tidak memenuhi syarat waktu kering sedangkan F2 dan F3 mengalami kenaikan waktu kering namun masih memenuhi syarat waktu kering masker wajah gel peel off. 
Kenaikan waktu kering selama masa penyimpanan 28 hari baik pada suhu ruang maupun suhu dingin dapat terjadi karena semakin lama waktu penyimpanan maka semakin lama pula sediaan terpengaruh oleh lingkungan, misalnya udara. Kemasan yang kurang kedap dapat menyebabkan sediaan menyerap uap dari dari luar sehingga menambah volume air dalam sediaan 8 . Selain itu, sediaan masker wajah gel peel off mengandung gliserin sebagai humektan sehingga kenaikan waktu kering juga dapat dipengaruhi oleh gliserin, gliserin yang bersifat higroskopis dengan afinitas yang tinggi untuk menarik dan menahan molekul air akan menjaga kestabilan dengan cara mengabsorbsi lembab dari lingkungan dan mengurangi penguapan air dari sediaan 17,19 .

\section{Uji Daya Sebar}

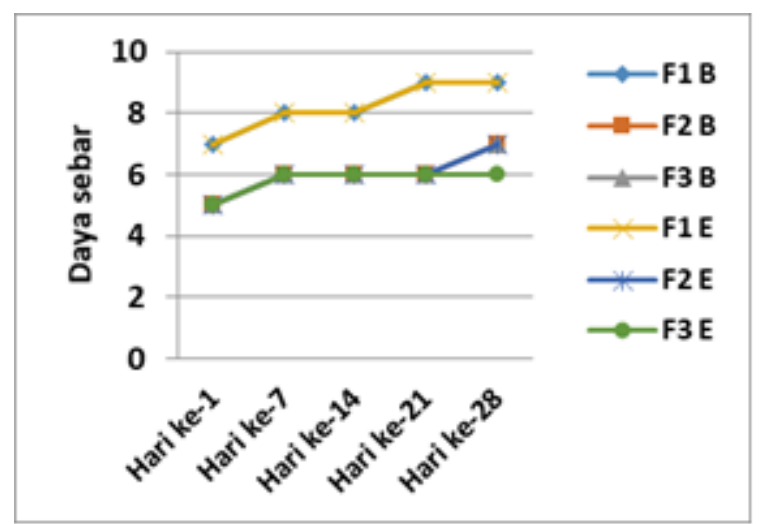

Gambar 5. Grafik Daya Sebar Masker Wajah Gel Peel Off Penyimpanan pada Suhu Ruang

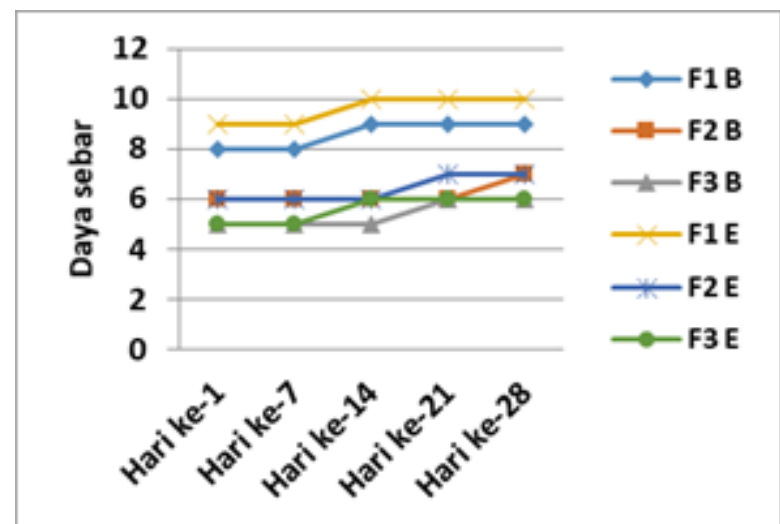

Gambar 6. Grafik Daya Sebar Masker Wajah Gel Peel Off Penyimpanan pada Suhu Dingin

Hasil uji daya sebar pada ketiga formula selama penyimpanan 28 hari dan pada suhu ruang maupun suhu dingin mengalami kenaikan daya sebar. Pada F1 tidak memenuhi syarat daya sebar, yaitu 5-7 cm ${ }^{11,12}$, sedangkan pada F2 dan F3 memiliki daya sebar yang masih memenuhi persyaratan. Kenaikan daya sebar dapat disebabkan karena viskositas mengalami penurunan, hal ini dijelaskan pada penelitian yang dilakukan oleh Sukmawati dkk., (2013) bahwa peningkatan konsentrasi PVA, HPMC, dan gliserin pada masing-masing formula menyebabkan penurunan daya sebar. Penurunan daya sebar terjadi melalui meningkatnya ukuran unit molekul karena telah mengabsorbsi pelarut sehingga cairan tersebut tertahan dan meningkatkan tahanan untuk mengalir dan menyebar ${ }^{17,18}$, dimana viskositas sediaan gel berbanding terbalik dengan daya sebar yang dihasilkan. 


\section{Analisis Statistik}

Berdasarkan hasil analisis menggunakan metode Kruskal - Wallis menunjukkan bahwa kadar kandungan PVA yang berbeda berpengaruh signifikan $(p<0,05)$ terhadap daya sebar masker gel. Serta tidak berpengaruh signifikan $(p>0,05)$ terhadap ph, viskositas, dan waktu kering. Berdasarkan hasil analisis statistik menunjukkan bahwa formula FI, F2, dan F3 berbeda bermakna $(p<0,05)$.

\section{Kesimpulan}

1. Formula masker wajah gel peel off ekstrak kulit buah naga merah dengan variasi konsentrasi polivinil alkohol (PVA) yang memenuhi syarat evaluasi fisik gel adalah F2 dengan jumlah PVA 10\% dan F3 dengan jumlah PVA 14\%.

2. Masker wajah gel peel off ekstrak kulit buah naga merah formula F2 dan F3 memenuhi syarat evaluasi fisik gel yang baik selama penyimpanan 28 hari pada suhu dingin yang meliputi uji organoleptik, uji $\mathrm{pH}$, uji daya sebar dan uji waktu kering.

\section{Daftar Pustaka}

1. Darsika, K.V, Sowmya., K, Suganya., Grace, X. Fatima., Shanmuganathan, S. 2015. "Research Article". Preparation and Evaluation of Herbal Peel Off Face Mask. American Journal of Pharmatech Research. 5(4).

2. Wulansari, Sri Dewi. Formulasi Masker Wajah Gel Peel Off Ekstrak Kunyit Putih (Curcuma mangga Valeton \& Zijp). Skripsi. Palu : Fakultas Matematika dan IImu Pengetahuan Alam Universitas Tadulako. 2014.

3. Dewi, Tri Sefti Puspita. Kualitas Losion Ekstrak Kulit Manggis (Garcinia mangostana). Skripsi. Yogyakarta : Fakultas Teknobiologi Universitas Atmajaya Yogyakarta. 2014.

4. Sunarni. 2005. Tanaman Berkhasiat Antioksidan. Cetakan ke-2. Penebar Swadaya. Jakarta.

5. Jaafar, Ruzainah Ali., Ridhwan, Ahmad., Mahmod, Nor Zaini Che., and Vasudevan, R. 2009. Proximate Analysis of Dragon Fruit (Hylocereus polyhizus). American Journal of Applied Sciences. 6(7).

6. Nurliyana, R., Zahir, Syed., Suleiman, Mustapha., Aisyah, and K. Rahim Kamarul. 2010. "International Food Research Journal". Antioxidant study of pulps and peels of dragon fruits: a comparative study. 17.

7. Ogur, E. 2005. "Rapra Review Report". Polyvinil Alcohol : Materials, Processing and Applications. Rapra Technology. 16(12).

8. Septiani, S., Wathoni, Nasrul., Mita, Soraya R. 2011. Formulasi Sediaan Masker Gel Antioksidan dari Ekstrak Etanol Biji Melinjo (Gnetum Gnemon Linn.). Jurnal Universitas Padjadjaran.

9. Tranggono, R.I., dan F. Latifah. 2007. Buku Pegangan IImu Pengetahuan Kosmetik. PT. Gramedia. Jakarta.

10. Vieira, Rafael Pinto., Fernandes, Alessandra Ribeiro., Kaneko, Telma Mary., Consiglieri, Vladi Olga., Pinto, Claudinéia Aparecida Sales de Oliveira., Pereira, Claudia Silva Cortez., Baby, André Rolim., and Velasco, Maria Valéria Robles. 2009. Physical and physicochemical stability evaluation of cosmetic formulations containing soybean extract fermented by Bifidobacterium animalis. Brazilian Journal of Pharmaceutical Sciences. 45. 
11. Garg, Alka., Aggarwal, Deepika., Garg, Sanjay., and K. Singla Anil. 2002. "Pharmaceutical Tecnology". Spreading of Semisolid Formulation: An Update. 26.

12. Mappa, Tiara., Edy, Hosea Jaya., Kojong, Novel. 2013. "Jurnal Ilmiah FarmasiUNSRAT". Formulasi Gel Ekstrak Daun Sasaladahan (Peperomia pellucida (L.) H.B.K) Dan Uji Efektivitasnya Terhadap Luka Bakar Pada Kelinci (Oryctolagus Cuniculus). 2(2).

13. Andaryekti, Rufi., Mufrod., Munisih, Siti. 2015. Pengaruh Basis Gel Sediaan Masker Ekstrak Daun Teh Hijau (Camellia sinensis Linn.) Pada Karakteristik Fisik dan Aktivitas Antibakteri Staphylococcus Aureus ATCC 25923. 11(2).

14. Rowe, Raymond C., Sheskey, Paul J., and Quinn, Marian E. 2009. Handbook of Pharmaceutical Exipients. Six Edition. London : Pharmaceutical Press. P. 283-285, 326-328, 441-443, 564-565, 596-597.

15. Beringhs, André O'Reilly., Rosa, Julia Macedo., Stulzer, Hellen Karine., Budal, Rosane Maria., and Sonaglio, Diva. 2013. "Research Article". Green Clay and Aloe Vera Peel-Off Facial Masks: Response Surface Methodology Applied to the Formulation Design. American Association of Pharmaceutical Scientists. 14(1).

16. Safaryani, Nurhayati., Haryanti, Sri., Hastuti, Endah Dwi. 2007. Pengaruh Suhu dan Lama Penyimpanan Terhadap Penurunan Kadar Vitamin C dalam Brokoli (Brassica oleracea L.). Buletin Anatomi dan Fisiologi. 15(2). P. 40.

17. Sukmawati, N.M.A., Arisanti, C.I.S., Wijayanti, N.P.A.D. 2013. Pengaruh Variasi Konsentrasi PVA, HPMC, dan Gliserin Terhadap Sifat Fisika Masker Wajah Gel Peel Off Ekstrak Etanol 90\% Kulit Buah Manggis (Garcinia mangostana L.). Jurnal Farmasi Udayana.

18. Martin, A., J. Swarbrick, and A Cammarata. 1993. Farmasi Fisik: Dasar-dasar Farmasi Fisik dalam IImu Farmasetik. Edisi Ketiga. Penerjemah: Yoshita. Jakarta: UI Press. Hal. 1124-1187.

19. Barel, A. O., M. Paye, and H. I. Maibach. 2009. Handbook of Cosmetic Science and Technology. Third Edition. New York: Informa Healthcare USA, Inc. Pp. 233, 261-262. 